\title{
The Dibao Recipients
}

Mollified Anti-Emblem of Urban Modernization

Dorothy J. Solinger

\section{CpenEdition}

Journals

Electronic version

URL: http://journals.openedition.org/chinaperspectives/4738

DOI: $10.4000 /$ chinaperspectives. 4738

ISSN: 1996-4617

\section{Publisher}

Centre d'étude français sur la Chine contemporaine

\section{Printed version}

Date of publication: 1 December 2008

Number of pages: $36-46$

ISSN: 2070-3449

\section{Electronic reference}

Dorothy J. Solinger, «The Dibao Recipients », China Perspectives [Online], 2008/4 | 2008, Online since 01 December 2011, connection on 10 December 2020. URL : http://journals.openedition.org/ chinaperspectives/4738; DOI : https://doi.org/10.4000/chinaperspectives.4738

(C) All rights reserved 
C

The Dibao Recipients

\author{
Mollified Anti-Emblem of Urban Modernisation
}

DOROTHY I. SOLINGER

\begin{abstract}
After the Chinese leadership became cognizant of the negative social externalities of marketization-especially potential threats to its hallowed objectives of social stability and successful state enterprise reform-it initiated a novel welfare approach, the dibao, to handle the people most severely affected by economic restructuring. I review the state's management of these people and the latter's experiences. I argue that they are seen subliminally (if not explicitly) by the elite as a menace to officialdom's modernization ambition. Hence, the dibao is structured so as to keep its targets quiet and out of view, now and into the future.
\end{abstract}

\section{Introduction}

$\mathrm{T}$ he Chinese party-state's switch to market incentives and competition-based compensation, while contributing mightily to the nation's modernity, has at the same time been at the very root of China's new urban poverty. Official concession that this is the case has sometimes been articulated quite openly, as in this statement:

Following the prosperous development of the socialist market economy, urban residents' rice bowl is no longer iron; adding on other unforeseen events, some staff and workers' basic livelihood has met with difficulty. ${ }^{(1)}$

The main point here is that the incidence of urban indigence shot sharply upward once state and collective enterprises were enjoined to cut back drastically on their workforces after the mid-1990s. At the same time, with the total overhaul of the socialist economy and its institutions, traditional welfare entitlements were also taken away, ${ }^{(2)}$ leaving losers at a total loss.

In the 1990s, the Chinese leadership became cognizant of and deeply concerned over these negative social externalities of marketisation. Most especially, its members agonised over the potential political impact of these deprivations on its hallowed objectives of social stability and a successful project of state enterprise reform. For securing these aims was deemed essential to the grander goal that has undergirded every undertaking of the post-Mao state: this is the modernity of the nation, particularly of its metropolises. Accordingly, the political elite initiated a novel welfare approach to handle the people most severely affected by economic restructuring - and therefore those most antithetical to the objective of smoothly sailing progress. These targeted persons constitute a category comprised of a never-before so sizable segment of the city populace: they were newly-minted, state-policy-provoked, dirt-poor urbanites living in the midst of what still calls itself "socialist China."

After a half dozen years of grass-roots experimentation, in the place of the old urban work-unit-grounded, relatively universal, automatic security entitlements granted by the enterprises in the municipalities of the socialist era, the state inaugurated a discretionary, means-tested cash transfer program, ${ }^{(3)}$ the Minimum Livelihood Guarantee (zuidi shenghuo baozhang), popularly referenced as the "dibao." If not in intent at least in fallout it is much akin to what Tony Judt has written of "modern welfare reform" in Western settings, in that both introduce "conditionality" into "social citizenship" by forcing the beneficiaries to "pass certain tests

This paper revises and condenses my paper "The Dibao: A Minimum Livelihood Guarantee to Guarantee Minimal Commotion," prepared for Workshop on Comparative Urban Marginalization and Poverty, Cardiff, UK, 12-13 June 2008.

1. Yuan Lanhua and Lin Chengmei, "Ai ru chao yong-Qingdaoshi chengxiang zuidi shenghuo baozhang zhidu shishi jishi" (Love like a rising tide-a true reporting of the Qingdao city urban and rural minimum livelihood guarantee system), Zhongguo minzheng (hereafter ZGMZ), 7 (1998), p. 10.

2. This point appears in an essay on an official website, "Zhongguo chengshi jumin zuidi shenghuo baozhang biaojun de xiangguan fenxi, jingji qita xiangguan lunwen" (Chinese urban residents' dibao norm's relevant analysis; economic and other related treatises) (hereafter "Zhongguo chengshi"), unpaged, http://www.ynexam.cn/html/jingjixue/ jingjixiangguan/2006/1105/zhonggochengshijimin, accessed 18 August 2007. The same point is made by Ya Ping Wang in Urban Poverty, Housing and Social Change in China, London and New York, Routledge, 2004, 60, pp. 71-87.

3. This term comes from Sarah Cook, "The Challenge of Informality: Perspectives on China's changing labour market," Paper for IDS Bulletin, 2008. 
and demonstrate appropriate behavior." ${ }^{(4)}$ Perhaps it is most surprising to find this practice in a state that for its urban residents was once considerably egalitarian and rather munificent.

The charge of the dibao was to provide for urban residents whose household income failed to reach a locally-determined minimal threshold; the method was to supplement that income to the extent necessary to bring the family's monthly wherewithal up to the level deemed requisite for basic survival in that region. ${ }^{(5)}$ The project was proudly labelled by its publicists a "standardised, legalised, social guarantee system," (6) a characterisation more aspirational than actual, especially at the time of the plan's national promulgation in September 1999. ${ }^{(7)}$ Much like "reformed" Western welfare programs, it reeks of distrust of its objects; unlike similar schemes in democracies, however, its administrators are ably assisted by the recipients' co-residents in their community courtyards.

The idea behind the policy amounted to supplying individuals with funds that were "just enough to keep body and soul together," in the words of its leading scholar within China, Tang Jun. ${ }^{(8)}$ Its upshot - intended or not - was to render the recipients, the dibao duixiang (minimum livelihood guarantee targets) or dibaohu (minimum livelihood households) politically pacified, socially marginalised, and excluded, silent, and discarded, the effectual detritus of the country's modern, metropolitan development. Thus a population whose plunge in plight was manufactured by a state-sponsored market incursion was set to be further manipulated by the powers-that-be.

And since the provisions of the program in many ways confine not just the payees but their progeny as well to long-term penury, operatively ensuring that all be denied any opportunity for upward mobility, it seems fair to see it as a ticket to membership in a permanent underclass. An irony is that even as a drive for modernity brought this grouping into being, these now-paupers - too old, too ignorant, too unskilled, too unwell ${ }^{(9)}$ - are themselves set to remain as unmodern dregs of the past, debris of the old, ousted order, unable to enter the gates to the future, placed thusly, presumably, in the interest of not threatening the nation's onward progress. ${ }^{(10)}$ The approach adopted appears to be an excellent way to ensure this result, as it tends to detain most of the recipients within their domiciles, due both to their bodily weakness and to their sense of shame. They are the antiemblem of China's urban modernisation.

In what follows, I examine the expressed aims of the policy; quantify the amounts of funds laid out over time; and outline the procedures for establishing eligibility and disbursing allocations, plus document attendant mishaps, misunderstandings, and misappropriations that attend the implementation of the program. My sources include 53 recipient families interviewed in Wuhan in the summer of 2007. ${ }^{(1)}$ The residents in the communities covered could be questioned because of personal connections with community officials. Thus, the "sample" consists simply of those dibaohu members found at home who were willing to speak with us. I also spoke with bureaucrats in charge of the program in Wuhan and Lanzhou, and with community (shequ) cadres at several Wuhan community offices. And I read documentary material from the journal of the responsible ministry, the Ministry of Civil Affairs, Zhongguo minzheng (China Civil Affairs); statistical yearbooks and annual social development "blue books" published by the Chinese Academy of Social Sciences; and official materials: government work reports, articles on the Internet, ${ }^{(12)}$ and documents collected in Wuhan and Lanzhou in August and September 2007.

I draw upon this material to undergird my argument above: that the thrust of the state's management over them, along with the nature of their own experiences, together signify

4. Tony Judt, "The Wrecking Ball of Innovation," Review of Robert B. Reich, Supercapitalism: The Transformation of Business, Democracy and Everyday Life, New York, Knopf 2007, The New York Review of Books, December 6, 2007, p. 24.

5. Artar Hussain et al., "Urban poverty in the PRC," Asian Development Bank Project No. TAR: PRC 33448. 2002.

6. Ding Langfu, Ding Langfu, Cong danwei fuli dao shehui baozhang - ji zhongguo chengshi jumin zuidi shenghuo baozhang zhidu de dansheng" (From unit welfare to social security - recording the emergence of Chinese urban residents' minimum livelihood guarantee system), ZBMZ 11 (1999), p. 7.

7. For the 1999 Regulations officially announcing the program, see "Chengshi jumin zuidi shenghuo baozhang tiaoli" (Regulations on the urban residents' minimum livelihood guarantee) (hereafter "Chengshi jumin"), ZGMZ11 (1999), pp. 16-17.

8. The Report of Poverty and Anti-Poverty in Urban China - The Poverty Problems in Urban China and the Program of Minimum Living Standard," (hereafter "The Report"), ms. 2002, p. 4. Portions of the report were later translated and published as Dorothy J. Solinger, guest editor: Tang Jun, "Selections from Report on Poverty and Anti-Poverty in Urban China," Chinese Sociology \& Anthropology Winter 2003-4/Spring 2004.

9. Not only were such individuals likely to lose their jobs in the massive shakedown of the late 1990s and early 2000s, but, lacking skills, they could rarely hope to find new work (Tang Jun, "Selections," Chapter Three). "Zhongguo chengshi" reports on an investigation that found that among adult targets, those with primary education and below represented 24.1 percent, while 46.5 percent had been to junior high school, together amounting to 70.6 percent without any senior high school training. A mere 27.6 percent of these people boasted of having some sort of professional or handicraft skill, while just 2.9 percent claimed to have some work. As for their health, the Ministry of Civil Affairs announced that in a national study of 10,000 dibao households, 33.7 percent have disabled people, and 64.9 percent had one or more members with a chronic or serious illness.

10. The mindset and rationale informing the project evokes the reasoning of Borge Bakken, The Exemplary Society: Human Improvement, Social Control, and the Dangers of Modernity in China (Oxford: Oxford University Press, 2000), pp. 59-74 and 433-34.

11. Interviews were in three Wuhan districts, 27-31 August.

12. I thank Kam Wing Chan for introducing me to a portal on the Web containing a wealth of official articles. 
that the dibaohu are seen subliminally (if not explicitly) by the elite as a menace to officialdom's modernisation ambition. Hence, a chief repercussion of the dibao's design is to keep its targets quiet and out of view, now and into the future.

\section{Stated goals}

The rhetoric of the program - especially its language of rights and self-reliance - belie its actual outcomes. The empowering 1999 Regulations proclaim that those households whose members, living together, have an average per capita income below that needed for a minimal livelihood "have the right to obtain material assistance with their basic livelihood"; they also allege that the policy is meant to "encourage self-support through labour" (13) (italics added). Yet little, in fact, appears in the speeches of top leaders - or in the great majority of pertinent government documents about either rights or economic autonomy. Most critically, the program has to date been administered such that there is no space for such possibilities. As Tang Jun reported in 2002, "The idea of dibao as a basic right hasn't penetrated to the recipients or to society at large yet." ${ }^{(14)}$

Soon after then-Premier Zhu Rongji had signed the order authorising the project in 1997, a Ministry of Civil Affairs official announced that the Party 15th Congress had authorised the project to "perfect the traditional social relief system, establish a wholesome modern social welfare system, and guarantee that the economic system reform, especially the state enterprises' reform, could progress without incident [shunli jinbu]" (15) (italics added). Once the program was underway, the Ministry went on to specify that the measure "relates to whether or not the state's reform and opening can penetrate and whether or not the socialist market economic system can develop in a healthy manner"; it also made a point of advising the localities to "spend a litthe money to buy stability." Zhu Rongji, ${ }^{(1)}$ reportedly an exponent of the project, visited the poorest of China's provinces on the eve of a massive injection of finances into it, and proclaimed that: "The dibao's support of social stability and guarantee of the reform of the state firms has important significance; we should strengthen it, should fund it. The centre and various local levels must all gradually increase its funds each year, and central finance should give necessary subsidies to places in financial difficulty." (17) Thus, the paired objectives of securing stability and facilitating the firms' reform lay at the core of the program's promulgation.
Various urban governments submitted reviews of their areas' execution of the project repeating these same themes. Fairly typical was Wuhan's announcement, unabashedly declaring the aim as "to help the enterprises throw off their worries and solve their difficulties" and "to lighten the enterprises' burdens." ${ }^{(18)}$ One writer went so far as to refer to the dibao as a "tranquiliser" that would permit the state enterprises in Shenyang's Tiexi District (a site of massive layoffs) to go forward without obstruction. For without it, this essayist penned, "these people must become a burden that the enterprises would find it hard to throw off... to the point of possibly arousing even larger social contradictions." ${ }^{(19)}$ Thus, as implementation became reality, the formal language of the empowering ordinance - with its bow toward the beneficiaries themselves - seems to have been overlooked.

Once the new administration of Premier Wen Jiabao had gotten underway, concern for the poor became linked to the new catchword, "harmony," which in essence could be taken as a rehashed label for stability. In 2007, a paper in the civil affairs journal emphasised that "the government demands that every place guarantee whomever should be guaranteed, to solve the livelihood problems of the urban poor to realise social stability" (my italics). ${ }^{(20)}$

Again, concern for the poor for their own sake is sadly missing from these pronouncements. But that sentiment is not altogether absent; it occasionally has appeared in the civil affairs journal. An outlier has been the director of the Ministry's Relief Office, Wang Zhenyao, who in 1996 termed the "issue of appropriately solving urban poor residents' livelihood difficulties" "an important task in the country's present economic and social development"; he also set ensuring the people's right to basic livelihood (jiben shenghuo quanyi) as in itself "an important component part

13. "Chengshi jumin, p. 16.

14. Tang Jun, "The Report," p. 35.

15. Wang Zhikun, "Chengshi jumin zuidi shenghuo baozhang: Buru fazhihua guanli guidao" (Urban residents' minimum livelihood guarantee: Step into the orbit of legalized managment) ZGMZ11 (1999), p. 18.

16. "Jianli zuidi shenghuo baozhang zhidu de jige wenti" (Several issues in establishing the minimum livelihood guarantee system), ZGMZ 9 (1996), p. 14.

17. Tang Jun, "Zhongguo chengshi jumin zuidi shenghuo baozhang zhidu de tiaoyueshi fazhan" (The leap forward style of development of Chinese urban residents minimum livelihood guarantee), in Ru Xin, Lu Xueyi, and Li Peilin, Shehui lanpishu: 2003 nian: zhongguo shehui xingshi fenxi yu yuce (Social blue book: 2003 analysis and predictions of China's social situation), Beijing, Shehui kexue wenxian chubanshe (Social science documents company), 2003, p. 243.

18. Meng Jiawu, "Wuhan chengshi zuidi shenghuo baozhang zhidu de sige tedian" (Four characteristics of Wuhan city's minimum livelihood guarantee system), ZGMZ, 7 (1996), p. 19.

19. Ding Langfu, op. cit., p. 7 .

20. "Zhongguo chengshi." 
of the government's role." (21) In short, for most of the program's publicists and practitioners, to become effectively "reformed" and thus sufficiently modern, China would need to keep disciplined the new underdogs to which its marketisation had given birth. This it has achieved not by satisfying but by subduing them.

\section{The mechanics and money constituting the program}

\section{operationalising the poverty line}

The Regulations formalising the system called for setting the outlays locally, in accord with the costs of the amount of food, clothing, and housing needed for minimal subsistence in a particular city. Designers of the program put urban authorities in charge of determining the line, since prices, the pattern of consumption, and the average income per capita vary geographically. Another reason was that cities were originally to fund at least a portion of the outlay, so a given municipality's financial capability was critically relevant as well. ${ }^{(22)}$ The cut-off line, set separately by and for each metropolis (and its own suburban areas), aims to subsidise households whose average per capita income falls below the amount necessary for purchasing basic necessities at the prices prevailing locally. The line was to be set below both the minimum wage and unemployment insurance benefits, supposedly to encourage beneficiaries to accept employment whenever possible. But this element had a draconian correlate: a recipient's acquisition of even a tiny increment in income through occasional labour could result in a drastic reduction of his/her household's dibao disbursement, so some (in my sample, one of 53) did feel disinclined to seek employment.

The bureaus of civil affairs, labour, finance, auditing, personnel, statistics, and prices, along with the local branches of the trade union, jointly stipulate and, when deemed necessary (as in times of inflation, when a city's financial receipts have had a good turn or when the standard of living among the general population of a city has risen), ${ }^{(23)}$ hike up the local cut-off line. ${ }^{(24)}$ Other departments were given other, related functions, e.g., the education bureau had to ensure that the targets' children's miscellaneous school fees were either reduced or cancelled, and medical departments were to do the same for medical treatment fees. ${ }^{(25)}$ In addition, most places created a special leadership small group, located within the bureau of civil affairs, to take overall control. ${ }^{(26)}$ All told, the financial situation of the city has a determining impact upon where the poverty line is set; poorer urban juris- dictions preferred to set the standard lower from the outset so as to minimise the numbers for which they would be responsible, whereas in cities with more revenue and where, often, the numbers of the poverty-stricken are fewer, the line is pegged at a higher level. Though initially it was projected that the costs would be shared relatively equally between the central government and the localities, in practice the portion born by localities has varied significantly, from sites where the city pays the bulk or even all of the allowances (as in the wealthy coastal region) to places where sizable assistance from the central government means that a locale bears almost none of the expenses (in the west). ${ }^{(27)}$

The authorising regulations divide the recipients into two types: those who fit the conditions of the old "three withouts," ${ }^{(28)}$ and those with some minimal income. ${ }^{(29)}$ "Three-

21. Wang Zhenyao and Wang Hui, "Luoshi chengshi jumin zuidi shenghuo baozhang zijin ying chuli hao wuge guanxi" (In order to implement urban residents' minimum livelihood guarantee funds we need to handle five relationships well), ZGMZ 3 (1998), p. 18.

22. The following comes from Artar Hussain et al., "Urban poverty in the PRC," Asian Development Bank Project No. TAR: PRC 33448. 2002, pp. 64-76. Wang Hui,"Chengshi zuidi shenghuo baozhang gongzuo zhi wo jian" (My opinion on the urban minimum livelihood guarantee work), ZGMZ, 10 (1996), p. 34, explains the concrete method for setting the line.

23. Some cities routinely raise the line every year or, in the case of Wuhan and some other places, every two years. Interview, head of the dibao section at the Wuhan Civil Affairs Bureau, 28 August 2007.

24. "Shishi zuidi shenghuo baozhang zhidu de sikao" (Reflections on implementing the minimum livelihood guarantee system), ZGMZ, 4 (1998), p. 20; the 1999 Regulations stipulated that the line could only rise, not fall. See Wang Zhikun, Wang Zhikun, "Chengshi jumin zuid shenghuo baozhang: Buru fazhihua guanli guidao" (Urban residents' minimum livelihood guarantee: Step into the orbit of legalized managment) ZGMZ11 (1999), pp. 18, 19.

25. Xu Daosheng, "Jiada gongzuo lidu, chengxiang quanmian tuijin-Guangdong sheng jianli chengxiang hu (cun) min zuidi shenghuo baozhang zhidu de zuofa" (Strengthen work, carry out fully in the cities and rural areas-Guangdong province establishes a method for an urban and rural (village) residents' minimum livelihood guarantee system), ZGMZ, 3 (1998), p. 10. The civil affairs departments provide these other offices with a name list of the dibaohu in their jurisdiction, and it is then up to the offices to provide the relief. The housing, legal aid, coal, water, and electricity departments have similar charges. Interview, Lanzhou, 5 September 2007, with the head of the dibao office under the Provincial Civil Affairs Department.

26. Mao Jiansheng, "Liguo limin de ningjuli gongcheng-Fan Baojun fubuzhang jiu chengshi jumin zuidi shenghuo baozhang zhidu jianshe hui benkan jizhe wen" (A cohesive project benefiting the nation and the people-Vice Minister Fan Baojun answers this journal's reporter's questions about the minimum livelihood guarantee system's construction), ZGMZ, March 1997, p. 5

27. Wang Zhenyao and Wang Hui, "Luoshi chengshi jumin zuidi shenghuo baozhang zijin ying chuli hao wuge guanxi” (In order to implement urban residents' minimum livelihood guarantee funds we need to handle five relationships well), ZGMZ 3 (1998), pp. 18, 19. Hussain, op. cit., p. 70 , writing in 2002, said that only 21 of the 31 provincial-level units contributed toward the cost of the dibao. But Tang Jun, "The New Situation of Poverty and Antipoverty," in Ru Xin, Lu Xueyi, Li Peilin, et al., ed., 2002 nian: Zhongguo shehui xingshi yu yuce (Shehui lanpishu): (Year 2002: Analysis and Forecast of China's Social Situatiuon (Blue Book on Chinese Society)), January 1, 2002. (FBIS Translated Text) states that, "With the exception of Beijing, Shanghai, Shandong, Jiangsu, Zhejiang, Fujian, and Guangdong, all the other provinces got the central government's financial subsidies."

28. This term refers to the original the original three welfare targets (those unable to work, those without means of livelihood, and those without family support).

29. This is the eighth point in the Regulations. For the Regulations, see "Chengshi jumin," p. 16. 


\section{Amounts of funds and their sources}

As the numbers of recipients rose over the years, the amount of money committed to the program mounted as well. According to a piece by Tang Jun, in 1999, the year of the State Council's promulgation of the program's Regulations, the central government allocated over 405 million Yuan, representing about 27 percent of that year's total expenditure of 1.5 billion to the dibao, the remaining portion being doled out by cities. In the next year, the total outlay doubled to three billion, of which the central financial contribution remained at the same percentage. But in 2001, when the program's funds reached 4.2 billion, the centre paid out more than half of the total (55 percent), or 2.3 billion Yuan. ${ }^{(34)}$

The year 2002 saw a major jump in the quantity of funds handed out, amounting to 10.53 billion Yuan, but the centre gave just 44 percent. ${ }^{(35)}$ Despite this hike in the handouts, even after extra funding was allocated in 2001 and 2002, an official report admitted that, as of early 2002, the average poverty line across all participating urban areas was a mere 152 Yuan per person per month, only 29 percent of 200l's average urban per capita income nationwide. ${ }^{(36)}$ In 2003 , as much as 15 billion Yuan was budgeted (of which the centre dispensed 9.2 billion, over 60 percent).

Regardless of what appears as a new generosity, in that year the actual average per person subsidy (the per capita supplement allocated to each person) was just 56 Yuan per month. ${ }^{(37)}$ By 2005, this average monthly per capita allowance had risen to 70 Yuan, with a probable annual total expenditure in the range of 19.5 billion. ${ }^{(38)}$ Even as disbursements multiplied in Yuan, however, the amount of the per capita supplement nationwide on average amounted to a piddling 9.2 percent of average urban per capita income. ${ }^{(39)}$ Two years later, at the end of 2007, when 22.709 million people (amounting to 300,000 people more than at the same point a year earlier), ${ }^{(40)}$ living in $10,656,000$ households, were enjoying the program, the average monthly poverty line around the country had gone up to 182.3 Yuan per person, a rise of 12.8 Yuan over the previous year. At the same time, the average subsidy nationwide had increased to 102 Yuan per person per month, 23 percent over $2006^{(4)}$ - an amount still less than 16 percent of the average urban income $(1,148.83$ Yuan). ${ }^{(42)}$

From a different angle, using Tang Jun's figures, the funds allocated to the dibao nationwide each year rose from a miniscule 0.113 percent of government expenditures in 1999 to a high of just 0.61 percent in 2003 (though dropping in 2006, down to only 0.50 percent). ${ }^{(43)}$ This average was pulled down by the millions of urbanites residing in smaller and poorer cities across the nation, where the portions of relief funding were truly paltry. Still, given the large increases in government revenue over these years, it is notable that the percentage of funding going to the dibaohu did not exhibit a greater rise over time, and that the numbers served remained relatively fixed around 22 million after 2002. It is hard to imagine that the households so aided could survive with any degree of satisfaction. It is also striking that the nourishment, educational, and health standards among the individual dibaohu have remained remarkably unchanged and essentially abysmal over the years, as documented by a

34. Tang Jun, "Jianli zonghe de zuidi shenghuo baozhang zhidu" (Establish a comprehensive minimum livelihood guarantee system), http://thjp.vip.sina.com/M.htm, accessed on 18 March 2008. Hussain, op. cit., 70 has different figures: he states that the total expenditure in 1999 was just 1.97 billion Yuan, and 2.2 billion in 2000, of which the central government contributed 20.3 percent and 24.1 percent, respectively. Since I must make a choice, I intend to base my analysis on Tang's figures, since he is in Beijing permanently and works closely with official figures on an ongoing basis.

35. 4.6 billion Yuan came from the central treasury and 5.93 billion from local governments. Xinhuanet (Beijing), 19 July 2002. Thanks to Jane Duckett for this citation.

36. "Zhongguo chengshi."

37. Tang Jun, "Jiasu zuidi shenghuo baozhang zhidu de guifanhua yunzuo" (Speed up the standardization of the minimum livelihood guarantee system), in Ru Xin, Lu Xueyi, and Li Peilin (eds.), Shehui lanpishu: 2004 nian: zhongguo shehui xingshi fenxi yu yuce (Social blue book: 2004 analysis and predictions of China's social situation), Beijing, Shehui kexue wenxian chubanshe (Social science documents company), 2004, pp. 117-18. Another source states that the average norm in 2003 nationwide was 149 per capita per month, which had increased to 162 , on average, by the third quarter of 2006, with the supplement rising from 58 to 80 Yuan per capita per month, on average, over those three years (See "Zhongguo jianli chengxiang shehui jiuzhu tixi 7 qianwan kunnan qunzhong ganshou wennuan yangguang" (China constructs an urban-rural social relief system, 70 million masses in difficulty feel warm sunshine), http://china.com.cn/txt/200611/30/content 7429928.htm.

38. Tang Jun, "Tiaozhengzhong de chengxiang zuidi shenghuo baozhang zhidu" (The urban and rural minimum livelihood guarantee system in adjustment), in Ru Xin, Lu Xueyi, and Li Peilin (eds.), Shehui lanpishu: 2004 nian: zhongguo shehui xingshi fenxi yu yuce (Social blue book: 2006 analysis and predictions of China's social situation), Beijing, Shehui kexue wenxian chubanshe (Social science documents company), 2006, pp. 165, 167

39. Ibid., 168.

40. "China's subsistence allowance system benefits urban, rural poor equally," accessed 24 January 2008, at http://english.people.com.con/90001/90776/6344770.html.

41. "National urban and rural residents, the minimum livelihood guarantee system for equal coverage," accessed 18 March 2008 at http://64.233.179.104/translate_c? $\mathrm{hl}=\mathrm{en} \& \mathrm{sl}=\mathrm{zh}-\mathrm{CN} \& \mathrm{u}=\mathrm{http}: / / \mathrm{jys} . n d r c . g o v . c n / \mathrm{xinxi} / \mathrm{t} 20080$.

42. According to Premier Wen Jiabao's annual government work report, delivered on 5 March 2008, the average annual per capita income for urbanites in 2007 was 13,786 Yuan, one twelfth of which (or the monthly average) is 1148.33 Yuan. The report can be found at http://www.china.org.cn/government/NPC CPPCC sessions2008/200803/18/content_12 (accessed 14 April 2008).

43. Calculations are based upon the figures for governmental expenditure in Zhonghua renmin gongheguo guojia tongjiju bian (Chinese People's Republic national statistical bureau, ed., 2007 Zhongguo tongji nianjian (China Statistical Yearbook), Beijing, Zhongguo tongji chubanshe (China Statistics Press), p. 279. Hussain, op. cit., p. 71, states that in 1999 the expenditure on the dibao amounted to 0.15 percent of total government expenditure. 
comparison of Tang Jun's research team's field notes from the late 1990s with my own interview material from 2007. ${ }^{(4)}$

\section{other subsidies}

In addition to the handout of cash, the dibao program provides special privileges for recipients, involving discounts or exemptions. Wuhan, to give one example, offered as many as 12 separate youhui zhengce (preferential policies) as of mid-2007, including reductions in rent and in the charges for water, food, electricity, fuel, and legal services, as well as freedom from paying medical registration and miscellaneous school fees, in addition to various subsidies. The city boasted of furnishing two more such policies than Beijing did. ${ }^{(45)}$ Far from all of my informants received these benefits, however; indeed, some had never even heard of them.

In 2007, a number of new appropriations were made, some locally and some centrally mandated. An example of the latter was a one-time bonus for coping with sudden spurts in the prices of pork and other food products, the amount dispensed to be determined by individual cities, ${ }^{(46)}$ and a program to aid students in vocational middle schools. ${ }^{(47)}$ Some municipalities set aside funds for the children of dibao families who were attending college. ${ }^{(48)}$ One district in Guangzhou distributed certificates permitting dibaohu to purchase 20 Yuan worth of goods, ${ }^{(49)}$ while Wuhan allowed poor university students from dibao households to apply for educational loans. ${ }^{\left({ }^{00}\right)}$ And the State Council authorised a low-income housing program, aimed especially at families living in financial hardship. ${ }^{(5)}$ To get a better sense of how the program operates on the ground, it is necessary to examine the official procedures and the pitfalls often entailed in pursuing them.

\section{Procedures and their pitfalls}

\section{Procedures}

The workaday execution of the program plainly doles out disgrace to its targets. Its urban management splits discretion among four levels: the city, the district, the street, and the "community" (shequ), a unit that replaced and absorbed several residence committees each in the early 2000s. All these jurisdictions share in reporting, registering, investigating, approving, issuing forms, making modifications, and filing cases. ${ }^{(52)}$ The province also has a role: along with the city and the county it formulates local policy, dispenses propaganda, and organises supervisory work. County and district civil affairs departments take charge of implementing the system within their areas, look into and approve applications, and issue certificates; the street offices handle registration, while serving as a lower-level examiner of cases; and the residents' committee (the community), which - situated among the families' homes, and staffed by individuals closely familiar with the target population - takes in the cases and performs the initial check-up and all subsequent reporting. ${ }^{(33)}$ Applicants' journey toward becoming recipients begins with a written entreaty, accompanied by documentary proof of their penury, to be submitted to the community office in charge. After filing the request, community officials have a certain amount of time (set locally, usually from five to ten days) to assess the candidate's needs and to attempt to verify the paperwork presented. Certification of a claimant's qualification can be a particularly invasive process, beginning with a thorough physical search of the household in question, along with close inquiry of its members. What follows is an alarmingly intrusive, sometimes even insidious, procedure, involving interviewing neighbours and visiting the candidate's place of work - if any - to make sure the applicant has spoken truthfully. Most embarrassing of all, the results of the scrutiny are to be posted upon a public board (the gongshilan) set in the midst of the community's common grounds, in order to solicit the views not just of immediate neighbours but of everyone in the community acquainted with the appli-

44. Tang Jun's notes are in "Selections"; mine are available upon request.

45. Interview, Wuhan dibao office, 28 August 2007.

46. "Youyu roujia dafu shangzhang, Hefei dibao duixiang mei ren huo 90 yuan butie" (Because of the large rise in pork prices, Hefei dibao recipients will each get a subsidy of 90 yuan), Jianghuai chenbao (Jianghuai morning paper), http://politics.people.com.cn/ GB/14562/6075338.html, accessed 6 August 2007.

47. "Xiangshou chengshi dibao zhengce jiating de zhongzhi xuesheng ke lingqu zhuxuejin" (Students in middle vocational schools whose families enjoy the urban dibao policy can get funds to help with schooling), Xinhuawang, 18 July 2007.

48. "Dibao jiating zinu shang daxue jiuzhujin tigaole" (The relief funds for the sons and daughters of dibao families who are going to college), Zhongguo Ezhou zhengfu menhu wangzhan (China Ezhou government portal website), 8 August 2007.

49. "Guangzhoushi Liwanqu dibaohu meiyue ke huode 20 yuan tihuoquan" (Guangzhou city's Liwan district's dibao households each month can get 20 yuan of goods certificates), Guangzhou ribao, 18 August 2007, accessed 20 August 2007, at http://news.xinhuanet.com/local/2007-08/18/content_6556887.htm.

50. "Wuhan huji pinkun daxuesheng kaishi shenqing shengyuandi xinyong zhuxue daikuan" (Wuhan registered poor university students can begin to apply for credit loans for school assistance at the student's [home] locality), Changjiang ribao (Yangzi daily), 2 September 2007.

51. "Shouquan fabu: Guwuyuan guanyu jiejue chengshi dishouru jiating zhufang kunnan de ruogan yijian" (Authorized announcement: Some opinions on the State Council's solving urban low-income families' housing difficulty), Xinhuawang, 13 August 2007 http://news.xinhuanet.com/politics/2007-08/13/content_6526964.htm, accessed on 14 August 2007.

52. Laid out in Meng Jiawu, op. cit.

53. Xu Daosheng, op. cit., p. 10 
cant family's true state of eligibility, and of everyone in a position to see the targeted family members' daily comings and goings. ${ }^{(54)}$ Communities managing the system as they are ordered to do use the board to proclaim how many members live in every payee household; how much money each one is receiving; what special subsidies it is being given; and how much "voluntary work" (such as neighbourhood sanitation, public security, guarding, or gardening) its relevant members performed in a given week, such activity being a necessary condition of enjoying the allowance, so long as one is physically able. ${ }^{(55)}$

Once the community officers have made their tentative appraisal of a case, the file goes up to the street level, where another week or so is spent reviewing the materials. Street officials' deliberations are also posted publicly on the community's board for neighbours' comments. After the same length of time has passed, the records are delivered to the district level, where managers do a re-examination. The judgments about those who so far have seemed to meet the necessary conditions must once again be subjected to yet one more humiliating public view and reaction. If and only if there are no objections from other residents, finally the City Civil Affairs Bureau gives its stamp of approval, and the candidate becomes a full-fledged "dibaohu."

Families accepted are then extended a "baozhangjin lingquzheng" (certificate for collecting the funds), which their head is to carry, along with his/her household registration booklet and identification card to claim the allowance from the bank, either monthly or by quarter, depending upon the method adopted in their community. Subsequent, regular inspections (sometimes as frequent as every three months, in other cases just every six ${ }^{(56)}$ ) are meant to certify that the family remains qualified to enjoy the subsidy. When a household's situation or income undergoes alterations (through a retirement, a death in the family, a new odd job, or health changes), the household head is to notify the relevant office in its community to arrange for stopping, reducing, or increasing its outlays. ${ }^{(57)}$

There are conspicuous variations in the approaches taken by different municipalities in administering the dibao. In a 1998-99 investigation of implementation in five cities, Tang Jun and his research group found that Lanzhou was employing a more mobilisational approach to its indigent than was Wuhan. Officials in Lanzhou "emphasised arousing the dibao targets' activism for production, encouraging and organising them to develop self-reliance." (58) Walking through Wuhan's streets after 2000, I discovered that nowhere in the city could shoe repair specialists be found operating outside, apparently banned by the authorities. And as of 2007 these cities plainly displayed a persistent divergence in administrative methods, with Lanzhou clearly offering its indigent more leniency for their sidewalk business than Wuhan. That year I encountered a talented but hard-up woman in Wuhan who complained that the fees for exhibiting her artwork on the streets had escalated substantially over time, until she was forced to abandon any effort to try to make sales. ${ }^{(59)}$

But in Lanzhou, all manner of curbside business was going on unobstructed, including stalls for fixing footwear as well as bunches of young men hawking political picture posters. ${ }^{(60)}$ In line with these observed differences, the section chief of the dibao office in the Gansu provincial civil affairs department, situated in Lanzhou, admitted that "if the chengguan" - (the police in charge of maintaining order in public spaces - the very same body that has often chased poor and unemployed persons off the avenues of Wuhan) "is too strict, the dibaohu cannot earn money. And letting them earn money is a way of cutting down their numbers. If their skill level is low, their only means of livelihood can be the streetside stalls they set up themselves." ${ }^{(6)}$ So it would seem that treatment of the targets in different municipalities can vary in notable ways, with critical consequences for poor peoples' income. Wuhan, emphasising beautiful, unencumbered thoroughfares, is the quintessential upwardly mobile "modernising" town, while Lanzhou seems to be prioritising providing its poor with a chance at prospering a little bit, if possible.

\section{Pitfalls and disentitlement: Exclusions and embezzlements}

The stated good intentions of the dibao program conceal two sorts of perverse outcomes, both producing ongoing rock-bottom destitution. The first sort often ends up denying funding to truly needy people. This can result from local regulations

54. Interview with officers at community $\mathrm{W}$, an area with about 1,600 residents, of whom only about one percent are dibaohu, on 30 August 2007.

55. Interviews at community $Y$ containing over 4,000 people, and community Z, both on 29 August 2007.

56. Interview with the director of the dibao office at the Gansu Provincial Civil Affairs Department, 5 September 2007.

57. Wang Zhikun, op. cit., p. 19. Interview with dibao workers at community X, where there are 1,099 households, of which 7.9 percent are dibaohu, 27 August 2007.

58. Tang Jun, "The Report," p. 25.

59. Interview 2, 26 August 2007.

60. Observations, 3 September 2007.

61. Interview, 5 September 2007, Lanzhou. 
that dictate the exclusion of persons who try in any way to upgrade a totally minimal existence, thereby consigning them and their offspring to a perpetual underclass. Similar in effect are practices that treat poor people "as if" they had payments coming to them that ought to have come but have not, again disqualifying appropriately indigent citizens from receiving the allowance. These sorts of prohibitions amount to marginalisation via state - even if just local state or local officials' - design.

The other sort of unintended outcome is one that evidently occurs sufficiently frequently as to be inveighed against in official documents and in informal conversation with program managers. This is an effect that arises as implementation leaves open channels for embezzlement, deception, and defrauding, usually on the part of the officials in charge, but also sometimes - how often is impossible to document - on the part of the program's participants. These behaviours achieve marginalisation by subversion of state design. But whether by means of dictates or by their debasement, both categories of activity achieve disentitlement.

\section{Exclusions: Marginalisation via state design}

The primary strategy cities use to bar seemingly deserving beneficiaries from the program - one mode of keeping them marginal (though perhaps not consciously so calculated) - is to disallow the dibao for households whose behaviour might help them ascend out of poverty. Ji'nan, for instance, ruled in August 2007 that anyone who had purchased a computer or who often uses a cell phone could not enjoy the dibao. ${ }^{\left({ }^{(62)}\right.}$ Beijing's regulations preclude persons who have bought cell phones, have arranged for their children to attend schools of their own choice or private schools, or keep any domestic pets. In Liaoning, using a household phone more than 15 percent more than the local dibao norm or even having received gifts whose value was above the poverty line disqualified potential partakers. In Hainan, having births outside the plan can disqualify an otherwise needy household. ${ }^{(63)}$ Some places banned people from becoming recipients if they had a family business, regardless of its profits or losses - even owning a firm losing money and incapable of supporting the family's livelihood could spark quarrels between civil affairs departments and an applicant. ${ }^{\left({ }^{(64)}\right.}$ In Wuhan, the following circumstances could deprive the destitute of succour: having a motorised vehicle (unless it was required because of disability); having electrical fees surpassing 15 Yuan per month, except in the high-heat months of July, August, and September, or phone fees beyond 40 Yuan per month; using a cell phone or other hand-held communication device (even if having obtained it as a gift or a loan); accessing the Web on a home computer; or "without reason raising hell and influencing public affairs, maltreating and threatening work personnel." Obviously, the final restriction can be loosely interpreted, so that anyone challenging a decision of the dibao administrators - even anyone who does meet the specifications could be thrown off the rolls. ${ }^{(6)}$

Also forbidden was arranging for a child to enrol in special classes for study or training; doing odd jobs for which the wages are hard to verify; or for a child to be studying with a foreigner. At least some grantees took that guideline seriously, as evinced in this quotation of a mother of a 16-year-old boy:

This year his grades could qualify him to transfer to the Number 3 Senior High School, a provincial-level keypoint institution. But I don't have the money and secondly, if it's discovered that there's a child in the family who has transferred to a keypoint high school, our dibao qualification would be eliminated. We can't take this risk. He really wants to study in that school, but he knows the family's conditions, so he doesn't demand it of me; I feel I have really let my son down. ${ }^{(66)}$

All these strictures condemn the poor to persisting in poverty, while keeping them from mixing into the wider and modernising society.

The "as if" ostracisations achieve the same purpose - reducing a locality's financial responsibility while locking the socially and physically lame outside the pale - if by other means. This style of work is justified thus: "Since household income is very difficult to determine, hidden employment is pervasive, and hidden income and assets [are known to exist], [so] flexible standards are adopted everywhere." ${ }^{67}$

62. "Jinan guiding maidiannao jingchang yongshoujizhe buneng xiangshou dibao" (Jinan regulates that those who bought a computer or often use a cell phone can't enjoy the dibao), Zhongguowang, 9 October 2006, china.com.cn, accessed 17 August 2007.

63. "Hainan guiding piaochang ji weifan jihua shengyuzhe bu de xiangshou dibao" (Hainan regulate that those who visiting prostitutes and violate birth planning cannot enjoy dibao), Zhongguowang, 4 September 2006, china.com.cn

64. "Zhongguo chengshi."

65. Interview at Community X, 27 August 2007.

66. Interview 6 .

67. "Zhongguo chengshi." 
According to this logic, families are sometimes rejected simply because their municipality has managed to reduce the funds it must allocate to the dibao by lowering its local poverty line, thereby cutting off families that need to be assisted. Some urban administrators first determine the amount of funds they are willing to assign to the program and then set the number of dibaohu accordingly. The most common contrary practice is to eliminate people with the ability to work who have not found employment by considering that they have received the wages they would have earned had they been on a job. Such reckoning "regards as income" salary or benefits that, properly speaking, ought to have been - but were not - paid to a person, using their city's minimum wage or unemployment insurance subsidy to assess the amount of the supposedly received income or benefit, and then treating that sum as if it were the person's actual income. ${ }^{(68)}$ Another variant is to count as part of a person's income the funds that his/her legal supporter ought to be giving him or her, even if $\mathrm{s} /$ he never really gets it. ${ }^{\left({ }^{(9)}\right)}$

Still, several interviewees in Wuhan found their families' dibao funds cut back or cut off when a member did take on some wage-earning work. In one case a wife's street-sweeping led to deductions that left four people to survive on some 500-plus Yuan per month. ${ }^{(70)}$ In another, the wife in a family of three bravely reflected:

We can still go on, use the dibao money to raise our son (then age 12) - each month we get a subsidy of 234 Yuan. Though it's not much, some is always better than nothing. The family has one person working, so the subsidy was lowered a lot. We're not thinking of arguing about it, we all are very submissive people, so we don't think of bickering over money. If you give us 200-plus Yuan it still can be of use. ${ }^{(71)}$

A third woman, aged 34, lamented, "People like us are at the age for working, but we have no skill or culture, basically can't find any good job." The questioner, pointing out that her husband had left town in search of odd jobs (dagong), and that she was managing a stall, inquired whether their monthly quota had therefore been decreased. "Yes," she replied, continuing:

It's a no-way affair [mei banfa de shiqing]. "In my stall in one month I can earn only so much money, his work also isn't stable, but now our work is calculated into our income, then they have to cut the subsidy. But this income fluctuates, sometimes we have it and some- times we don't. Only relying on the dibao, that little money, means that basically there's no way to live."(2)

\section{Embezzlement and other violations: Marginalisation via subversion of state design}

More concealed than the practices detailed above - which are rationalised by resort to local regulations (though criticised in central-level documents and articles) - are outright violations of the policy, committed by parties on both sides. First of all, administrators may not receive the funds they should, quite likely because some of the money disappears along the way down the hierarchy to their offices. As one analyst expressed it, "there's a black box" containing the intermediary links set up to allocate the capital. ${ }^{(73)}$ In places with real financial shortages, provincial treasuries appropriate some of the funds for other purposes. ${ }^{(74)}$ In the poorest, most backward places, preferential policies often are not observed; even where funds are sufficient, departments that should make the mandatory discounts do not find it in their financial interest to comply. ${ }^{(75)}$

Dereliction of duty can take other forms, too, such as playing favourites among target families. ${ }^{(76)}$ According to one report, just as with any allocation of funds in China today, there are management personnel who, in reporting upward and approving applicants' files, "don't take an impartial standpoint to reflect the true situation but use their public office for private gain, give priority to their own friends and relatives, use the dibao to exchange favours, or take the state's money and put it into their own personal accounts." (77) And one study found that on average families actually obtain 36.5 Yuan less than is reported to upper levels to have been distributed. ${ }^{(78)}$ These stratagems keep the deck stacked against the deserving.

68. "Chengshi dibao: Tashang xin zhengcheng" (The urban dibao: step onto a new journey), ZGMZ 1 (2000), pp. 24-5

69. "Zhongguo chengshi."

70. Interview 8.

71. Interview 11.

72. Interview 12.

73. Tang Jun, "Zhongguo chengshi," p. 247.

74. Tang Jun, "The New Situation."

75. "Zhongguo chengshi."

76. "Chengshi jumin," p. 17.

77. Gong Guozheng, "Dibao" zhong de jizhong cuowu renshi” (Several kinds of mistaken understandings in the dibao) ZGMZ 4 (2000), p. 34

78. "Zhongguo chengshi." 
There are instances of dishonesty among the targets, too. According to journal articles, some dibaohu falsely report their income, forge documentary evidence, or otherwise conceal their earnings or assets. This is surely true in some instances. But it was striking how close the per capita income was that many Wuhan respondents revealed to us. These so similar self-reports would seem to suggest that those informants willing to disclose their monthly intake were telling us the truth.

Civil affairs essayists often criticised what they depict as "mistaken thinking" among the beneficiaries. This entails "tak[ing] the responsibility they themselves should bear and push[ing] it off to society and to the government," demanding, for example, that the state give their elderly parent a supplement, even when there are five or six siblings who could shoulder the burden. Others "of strong body" "refuse to use their two hands to work but instead play cards all day, out of love of ease and hatred for work," or so it is claimed. Then there are those who, lacking the proper qualifications, view the dibao as a basic right, or want it just because others have it, "stretching out their hands" under the supposition that everyone should get a share. Yet others, just because they have been laid off, believe they naturally deserve the allowance, whether they have a job or not, and even if they have an adequate source of income. ${ }^{(79)}$ One Wuhan community leader inveighed against residents in ill health whose necessary outlays go beyond their means, but who fail to comprehend that the dibao is based on income, not on a household's mandatory expenditures, and thus is not geared to help people meet all their costs. Alluding to "dingzihu," or troublemakers, she complained of "residents who create unusual difficulties," such as those who "clearly don't fit the criteria for getting the dibao but still press for it," often "run[ing] about shouting verbal threats." ${ }^{(80)}$ It would seem that the city might find the funds to absorb such malcontents into the fold, thereby rendering their existence less terribly bitter.

\section{Conclusion}

The dibao program was admittedly put into place to do nothing more than meet the most minimal requirements of the targeted needy. Its recipients were to be kept alive but muted, in the interest of rendering China modern without their interference, whether that interference might transpire out on the roadways as they eke out an unsightly sustenance or whether they otherwise venture outside to rail. Above all, they were not to disturb the forward march of the nation onward toward progress, which their uncultured and unwell persons seemed prone to sully.

Perhaps without actively and specifically intending to mould their situation in this way, the state has dealt with these dibaohu in a manner that keeps them and their children either sickly and therefore off the streets or else insufficiently schooled to advance in society, out of work, and eating too little to grow strong. And those able to improve their prospects by providing extra education for their children or by using computers, or to brighten their existence by communicating on cell phones or by seeking entertainment, become for these reasons ineligible. No leader of the country would be apt to acknowledge the playing out of this subtext. But I have demonstrated that both the regulations that shape this program and the regimens used in enforcing it - whether by design or by subterfuge - marginalise the most indigent among the urbanites. As they do so, they succeed in forging what for China is an unaccustomed - if mostly invisible underclass, plus purely pristine, and seemingly totally unsullied, modern, "civilised" cities. • 79. Gong Guozheng, "Dibao zhong de jizhong cuowu renshi” (Several kinds of mistaken un-
derstandings in the dibao) ZGMZ 4 (2000).
80. Interview, Community V. 